\title{
PERCEPTIONS AND ATTITUDES OF SECONDARY SCHOOL STUDENTS IN KWAZULU- NATAL TOWARDS VIRGINITY TESTING
}

\section{Professor Myra Taylor}

$\mathrm{PhD}$

Professor and Research Manager, Department of Public Health Medicine, Nelson R Mandela School of Medicine, University of KwaZulu-Natal

Corresponding author: Taylor@ukzn.ac.za

\section{Mr Siyabonga B Dlamini}

MPH student

Researcher, Department of Public Health Medicine, Nelson R Mandela School of Medicine, University of KwaZuluNatal

\section{Dr Reshma Sathiparsad \\ $\mathrm{PhD}$}

Lecturer, School of Social Work and Community Development, University of KwaZulu-Natal

\section{Professor Champaklal Jinabhai \\ $\mathrm{MD}$}

Head of Department of Public Health Medicine, Nelson R Mandela School of Medicine, University of KwaZulu-Natal

\section{Professor Hein de Vries \\ $\mathrm{PhD}$ \\ Professor, Department of Health Education and Health Promotion, Maastricht University, Netherlands}

Keywords: virginity testing; rural secondary school students; gender equity

\begin{abstract}
This study describes the prevalence of virginity testing (VT) amongst rural secondary school students in KwaZuluNatal (KZN), compares the attitudes of students of both sexes to $V T$, the differences in attitudes between girls who would/would not undergo such testing, and explores the relationship between risky sexual behaviour and girls who underwent virginity testing. A cross sectional descriptive study was undertaken with stratified random sampling of 10 secondary schools in Ugu District, KZN. Of 846 isiZulu-speaking students whose mean age was 16.1 years (SD 2.4), 492 (58.2\%) were girls, of whom 286 (58.1\%) had undergone VT and, in total 347 (70.5\%) girls supported VT. Girls whose mothers had less formal education were more likely to have participated in VT (P-0.03) with fewer older girls participating $(P=0.0003)$. More girls than boys considered $V T$ to protect against sexually transmitted infections (STIS) ( $P=0.02)$, and to be empowering ( $P<0.005)$, but $V T$ received support from both sexes as a traditional cultural practice. Participation in VT failed to prevent sexual intercourse and sexually transmitted diseases or to improve rates of condom use amongst those who were sexually active. South Africa's Bill of Rights supports gender equity. At community level VT has support despite its conflicting relationship with human rights, and questionable impact on preventing HIVIAIDS.
\end{abstract}

\section{OPSOMMING}

Hierdie studie beskryf die voorkoms van maagdelikheidstoetsing (MT), by plattelandse sekondêre skoolleerders in KwaZulu-Natal en vergelyk die houdings van leerders van beide geslagte in verband met $M T$, die verskille in houdings tussen dogters wat sodanige toetsing sal/nie sal ondergaan nie, en verken die verhouding tussen dogters wat 
maagdelikheidstoetsing ondergaan het en riskante seksuele gedrag. ' $n$ Kruisseksionele studie is onderneem met gestratifiseerde steekproefneming van 10 sekondêre skole in die Ugu distrik. Van 846 isiZulu-sprekende leerders was die gemiddelde ouderdom 16.1 jaar (SA 2.4), 492 (58.2\%) was dogters, van wie 286 (58.1\%) MT ondergaan het, en in totaal het 347 (70.5\%) dogters MT ondersteun. Dogters wie se moeders minder formele opleiding ontvang het was meer geneig om aan MT deel te neem( $P$-0.03) met minder ouer dogters wat deelgeneem het $(P=0.0003)$. Meer dogters as seuns het MT beskou as beskerming teen Seksueel-Oordraagbare Infeksies (SOIs) ( $P=0.02)$, en as bemagtiging $(P<0.005)$, maar MT het ondersteuning van beide geslagte as ' $n$ tradisionele, kulturele praktyk ontvang. Deelname aan MT kon egter nie seksuele gemeenskap verminder, ' $n$ toename in die gebruik van kondome verhoog, ' $n$ toename in die gebruik van kondome by diegene wat seksueel aktief was of seksueel-oordraagbare infeksies voorkom nie. Die Suid-Afrikaanse Handves van Menseregte ondersteun geslagsgelykheid. MT op gemeenskapsvlak ondersteuning ontvang ten spyte van die teenstrydige aspekte daarvan met betrekking tot menseregte, en die twyfelagtige impak daarvan op die voorkoming van MIVIVIGS.

\section{INTRODUCTION}

The traditional Zulu custom of virginity testing (VT) fell into disuse over past decades, but with the HIVIAIDS epidemic communities in Southern Africa are exploring strategies to control the devastation being wrought by diseases such as these (Reuters, 2001:1). As a result of the government's awareness campaigns the majority of people in rural communities, including primary school children, know that most HIV infections are transmitted through sexual intercourse (Taylor, Jinabhai, Dladla, Rangongo \& Connolly, 2000:100-107; Shisana \& Simbayi, 2002:82-84). However, despite this knowledge, the rate of HIV infection has rapidly increased, and sentinel site surveillance of women receiving antenatal services at public clinics in KwaZulu-Natal, reported an increase in the prevalence of HIV infection from $2 \%$ in 1992 to $40.7 \%$ in 2004 , with young women under the age of twenty years being at greatest risk of HIV infection. (Department of Health (DOH), 2002:7; DOH, 2005:8). Shisana, Rehle, Simbayi, Parker, Zuma, Bhana, Connolly, Jooste and Pillay (2005:21), in a national household survey, reported that $29.5 \%$ of South African females between the ages of 15-49 years were infected with HIV, and KwaZulu-Natal was found to be the province with the second highest number of people living with HIVIAIDS. An additional concern is the fact that South African youth initiate sexual intercourse at an early age (Buga, Amoko \& Ncayiyana, 1996:523527, Manzini, 2001:144-151; Taylor, Dlamini, Kagoro, Jinabhai, Sathiparsad \& De Vries, 2002:69-74; Reddy, Panday, Swart, Jinabhai, Amosun, James, Monyeki, Stevens, Morojele, Kambaran, Omardien \& Van Den Borne, 2003:51-56). The high rate of teenage pregnancy (35\%) among 15-19 year old females indicates the lack of other contraception and/or condom use $(\mathrm{DOH}$, 1998:142). In addition, young people have multiple partners, placing themselves at increased risk of infection (Taylor, Dlamini, Kagoro, Jinabhai, Sathiparsad \& De Vries, 2002:69-74). To address these serious problems, prevention strategies aim to delay sexual initiation or promote consistent condom use. Virginity testing aims to achieve the former and has support despite its negative impact on equity since only the female partner is deemed to be responsible for the spread of HIVIAIDS (Sathiparsad \& Taylor, 2006:117-137). The study describes the prevalence of the cultural practice of virginity testing (VT), which contradicts South Africa's efforts to promote gender equity, amongst rural secondary school students in KwaZulu-Natal. The study compares the attitudes of students to VT, differences in attitudes between girls who would and those who would not undergo such testing, and explores the relationship between girls who underwent virginity testing and their risky behaviour.

Virginity testing has been revived by communities in order to prevent girls from becoming sexually active. There is often social pressure to participate in virginity testing although such testing has been opposed as ineffective, unhygienic, and a violation of human rights (Murphy, 1999). An important strategy towards reducing the incidence of HIVIAIDS would be to delay the onset of sexual activity amongst young women. However, Harrison, Xaba, Kunene and Ntuli (2001:69-78) report that although young women in rural KwaZuluNatal agreed that sex should be delayed until the late teens or even early twenties, this rarely happened since girls were afraid that their boyfriends would leave them for other partners. Virginity testing is carried out by 
older women in each community who have developed a reputation for their competence (Leclerc Madlala, 2001:533-553). Although virginity testing cannot be justified scientifically, there is a belief that proof of virginity can be obtained by observing the female genitalia (Murphy, 1999). Proponents believe that it empowers girls and reduces their risk of HIVIAIDS and teenage pregnancy, and uncovers cases of rape or child abuse. On the other hand, opponents of the practice emphasise that it is unconstitutional, unhygienic and violates the human rights of those being tested. It is further maintained that such practice contradicts South Africa's Bill of Rights which promotes gender equity (Reuters, 2001:1; Constitution, 1996:7-37). An important question is whether support for virginity testing translates into girls choosing abstinence, and whether this could be a strategy to delay the initiation of sexual intercourse. Is this cultural practice a feasible approach to reducing the incidence of HIV in KwaZulu-Natal? Not all girls were involved as VT is not being systematically implemented and many girls live in areas where the practice does not occur.

The conceptual framework in designing the study was the I-Change behavioural model which was used to investigate students' perceptions about VT (De Vries, Mudde, Leijs, Charlton, Vattiainen, Buijs, Pais, Clemente, Storm, Gonzalez Navarro, Nebot, Prins \& Kremers, 2003:611-26). This model can be considered to be an elaboration of other social cognitive models, including Social Learning Theory and the Theory of Reasoned Action (De Vries, Backbier, Kok \& Dijkstra, 1995:237-257). The I-Change Model which has been extended from the ASE (Attitudes, Social Influence SelfEfficacy) Model (De Vries et al. 1995:237-257) seeks to understand the determinants of the behaviour and postulates that three types of cognitive factors influence an individual's behaviour. These are an individual's attitude, (in this study whether attitudes were positive or negative towards VT), social influences (in this study, support for and pressure against undertaking VT) and self-efficacy (this concept describes the individual's perceptions about her ability to implement the behaviour - namely to participate in VT). The theory suggests that these concepts will influence the person's intention to participate in VT and subsequent behaviour. The study thus investigated these determinants and whether the practice of VT protected girls from sexual risk behaviour.
The aim of this study was to explore the attitudes and perceptions of African rural secondary school students towards VT, and its possible role as a preventive strategy to delay sexual intercourse and thus to reduce the incidence of HIV infection. The objectives were to investigate the prevalence of the cultural practice of virginity testing amongst different age groups, to compare the attitudes of students of both sexes to VT, and to compare the opinions of girls who would choose VT with those who would not choose to undergo such testing. The final objective was to elucidate whether girls who underwent VT were less sexually active, reported fewer sexually transmitted infections (STIs) and engaged less in other risky behaviour such as the use of substances.

\section{METHODOLOGY}

\section{Research design and context}

A cross sectional descriptive study was undertaken in order to determine the prevalence of VT and factors influencing the practice. The research context was Ugu, a rural area situated in southern KwaZulu-Natal, and selected as similar to the other disadvantaged rural districts in the province, where most people live in wattle and daub homesteads scattered over the hills and valleys. There is high unemployment (26-40\%), and inadequate provision of services with only churches, schools, a few clinics and numerous small trading stores in the area (Statistics South Africa, 2000:43).

\section{Sample}

A stratified random sample of ten rural secondary schools (selected from the twenty-eight secondary schools in the district using random numbers) was selected, based on school size (number of students $<500$ and $>500$ ). One class of students in the lowest grade (grade eight) and a class from the middle grade (grade ten) of each school were randomly selected and all the students in these classes were invited to enroll in the study. There were no refusals from students or schools and the number of students per school who completed the questionnaire ranged from 64 to 122.

\section{Data gathering instrument}

A questionnaire was developed for the purpose of the 
study based on the I-Change Model and one section of the questionnaire investigated virginity testing. Demographic information included gender and age. A behavioural question assessed female students' practices (Have you ever participated in VT?). This study also assessed students' beliefs and attitudes regarding the advantages and disadvantages of virginity testing. Motivational aspects were assessed through questions exploring attitudes to VT with questions measuring the perceived advantages and disadvantages of VT as viewed by both male and female students. Both male and female students were asked about VT as a preventive strategy against pregnancy, STIs and HIVIAIDS and in addition, students were asked to select all the advantages and disadvantages with which they agreed. The possible advantages (seven questions) of VT were: "girls are proud of their virginity", "parents can be proud of their girls", "girls will be scared to have sex", "teaches girls to be of good character", "promotes abstinence from sex", "girls can have confidence in themselves", "girls won't have multiple sex partners". The perceived disadvantages of VT were as follows: "no disadvantages because it is a traditional practice", "many girls who are not virgins are disappointed", "those who are not virgins mock the others", "some girls cheat by pretending they are virgins", "the VT examiners charge a fee for their services", "VT examiners sometimes fail to do a good job", "you're forced to go even if you don't want to", "parents show distrust in you", and "it's degrading to girls".

Social norms and pressure to participate in VT were assessed by asking the participant's beliefs and experiences relating to VT. Social pressure was investigated by one question as to whether the girls felt pressured to undergo VT (yes/no). Intention to participate in VT was assessed by one question measuring intention to participate in VT if requested to do so. In addition, female students were asked to list those who would support their participation in VT and from whom pressure not to participate could be expected. They were also asked whether they engaged in the following risk behaviours: use of alcohol, tobacco and cannabis, whether sexually active, whether they had used condoms when last having sexual intercourse, and whether they had ever had a sexually transmitted infection. For these questions the responses were required to give yes/no responses.
The items in the questionnaire were developed through prior focus group discussions at different rural schools and the validity of the questionnaire was checked when piloting the instrument at two rural schools not included in the study. No qualitative data is reported in this paper.

The questionnaire was developed in English, translated into isiZulu and then retranslated to ensure clarity. To ensure consistency, the same research process was followed at each school. Confirmation of the validity of the instrument was based on similar responses provided by students at the different schools. Discussions held with female teachers at some of the schools served as further confirmation of the findings and they reported that the girls who confided in them that they had been tested expressed pride in their results.

\section{Procedure}

Students at each school completed an anonymous questionnaire in their classrooms supervised by fieldworkers; teachers were not present. It was explained that their answers were confidential and that at the end of the session participants would place their self-reporting questionnaires in an envelope which they then sealed.

\section{Data management and analysis}

The data were double entered using Epi-Info 6.04 and analysis was carried out using SPSS 11.5 statistical packages. The prevalence of VT was analysed by univariate analysis. The attitudes of students of both sexes to VT were compared through bivariate analyses (Chi-square), as were the opinions of female students who supported/did not support VT, since not all female students would have had the opportunity of participating in VT.

Analysis was undertaken to investigate associations between VT and sexual activity and sexually transmitted infections using the Chi-square distribution. Models were developed using logistic regression to determine whether virginity testing was positively associated with risk behaviours such as sexual activity, sexually transmitted infections, use of condoms, and substance use (alcohol, tobacco and cannabis). 


\section{Ethical clearance}

Ethical approval to undertake the study was obtained from the Ethics Committee, Nelson R Mandela School of Medicine, University of KwaZulu-Natal, and permission to undertake the study was obtained from the KwaZulu-Natal Department of Education and Culture. Permission was also obtained from each of the school principals, and written informed consent was obtained from both the parents of participating students and the students themselves.

\section{RESULTS}

The mean age of the 846 participants was 16.1 years (SD 2.4) with girls (493) comprising over half (58.2\%) of the number of students.

\section{Prevalence of Virginity Tested Girls}

Amongst these girls, 286 (58.1\%) had undergone virginity testing (VT), and of all the girls, $347(70.5 \%)$ indicated that they supported the practice and would choose to participate. There was a significant difference in the proportion of girls who had undergone virginity testing at the different schools, ranging from $19.5 \%$ to $83.7 \%$ $(P<0.005)$, with no obvious geographical or other reason for this disparity.

There was also a significant difference concerning support for being tested in the future amongst girls of different age cohorts. Most girls under fifteen years of age were keen to be tested $(80.1 \%)$, but this decreased to $69.8 \%$ amongst sixteen to eighteen year olds, and significantly fewer older students (namely, $52.6 \%$ of those above eighteen years of age) would choose to participate $(P=0.0003)$. However, amongst girls who had previously undergone $V T$ there were no similar age differences $(P=0.22)$. Girls whose mothers had a lower standard of education were significantly more likely to have undergone virginity inspection (Chi-square 10.89, $\mathrm{P}=0.03$ ).

\section{Attitudes of students (males and females) to Virginity Testing}

Both sexes were asked their views as to whether VT could prevent pregnancy, HIVIAIDS and sexually transmitted infections (STIs).
Significantly more girls than boys reported that $\mathrm{VT}$ would protect against STIs $(P=0.02)$. There was also a trend amongst girls supporting VT as protective against pregnancy $(P=0.07)$, but less than half of the students of both sexes thought that VT would protect against HIV/ AIDS.

Students were asked to indicate their perceptions about the advantages and/or disadvantages of virginity testing. There were significant gender differences in respect of students' perceptions about virginity testing, with girls perceiving more advantages than boys, but both sexes had similar attitudes concerning the disadvantages of VT. More than half of the students accepted the practice as beneficial because it was a cultural practice, and few of either gender considered the practice to be degrading to girls. Many girls felt that it gave them reason to be proud of themselves and this was supported by half of the boys. Of the girls $30.4 \%$ believed that VT decreased the likelihood of sexual activity and $54.6 \%$ believed that it enabled parents to be proud of their daughters. Few of the girls perceived the practice as disempowering. Perceived disadvantages of VT related to the attitudes of girls who were not virgins who mocked the others, the motivation and competence of testers, and to a lesser degree, parental coercion (Table 2).

Girls reported that most of the support for VT came from the female members of the family and in particular from mothers $(74.1 \%)$ and sisters (23.3\%). Boyfriends $(49.6 \%)$ and other friends $(27.2 \%)$ did not support the practice.

Of the girls in this study $70.5 \%$ reported that they would participate in VT if requested, $26.2 \%$ would not participate and $3.5 \%$ did not answer this question. Table 3 confirms that many rural female students perceived advantages from VT and believed that the practice should be supported as part of Zulu culture. Significant differences were found relating to issues such as support for virginity, parental pride in their daughters remaining virgins and the role of VT in promoting sexual abstinence. Significant differences regarding the disadvantages of VT was found relating to perceptions of parental distrust and peer pressure with girls who were not virgins scoffing at those who participated.

A similar analysis was undertaken to determine whether there were any differences in the beliefs, attitudes and 
Table 1: Demographic profile of Ugu, KwaZulu-Natal rural secondary school students, $n=846$

\begin{tabular}{|l|l|}
\hline Students & Number \\
\hline Females & $493(58.2 \%)$ \\
Males & $353(41.8 \%)$ \\
\hline Grade 8 & $350(41.4 \%)$ \\
Grade 10 & $496(58.6 \%)$ \\
\hline Mean Age (years) & $16.1($ SD 2.4$)$ \\
Females & $15.9($ SD 2.5$)$ \\
Males & $16.3($ SD 2.4$)$ \\
\hline Students were first language isiZulu speakers. \\
\hline
\end{tabular}

Table 2: Students' perceptions of Virginity Testing (VT) as a preventive strategy for risk behaviours, by gender (Number, \%), n=846

\begin{tabular}{|l|l|l|l|l|l|}
\hline $\begin{array}{l}\text { VT prevents } \\
\text { risk behaviour }\end{array}$ & $\begin{array}{l}\text { Males } \\
\mathbf{n = 3 5 3} \\
\%\end{array}$ & $\begin{array}{l}\text { Females } \\
\mathbf{n = 4 9 3} \\
\%\end{array}$ & $\begin{array}{l}\text { Total } \\
\text { Students } \\
\mathbf{n = 8 4 6} \\
\mathbf{( \% )}\end{array}$ & $\begin{array}{l}\text { Chi } \\
\text { Square } \\
\text { Value }\end{array}$ & $\begin{array}{l}\text { Value } \\
\end{array}$ \\
\hline Pregnancy & 56.1 & 62.0 & 59.4 & 0.00 & 0.07 \\
\hline STIs & 46.2 & 54.4 & 50.8 & 4.38 & 0.02 \\
\hline HIVIAIDS & 47.3 & 47.9 & 47.6 & 3.37 & 0.84 \\
\hline
\end{tabular}

the social support/pressure amongst younger $(<16$ years) and older ( $>16$ years) students of both genders. Significantly more older students indicated that VT demonstrated that girls were of good character $(57.9 \%$ versus $42.1 \%, p=0.04)$, and that girls would be scared to have sex $(55.6 \%$ versus $44.4 \%, p<0.0001)$.

In response to whether they were pressured to participate in VT, the majority of the girls who had been tested $(63.9 \%)$ reported no pressure, $10.2 \%$ felt pressured and $25.9 \%$ reported feeling very pressured. Thus amongst girls who had been tested, a third reported being pressured. However, of the girls who had not undergone virginity testing, $65.6 \%$ stated that they would participate given the opportunity.

\section{Relationship between VT and sexual risk behaviour}

Most $(68.2 \%)$ of the $n=347$ girls who would choose to participate in VT, indicated that they were not sexually active. However, of 48 female students who had had sex in the past month, $\mathrm{n}=11(22.9 \%)$ indicated that they would participate in VT if requested. Eighteen percent of the girls who were not sexually experienced, would choose not to take part in VT.

There were no significant differences in the prevalence of reported sexually transmitted infections (STIs) amongst tested/non-tested girls (Chi-square 2.77, $\mathrm{P}=0.15$ ). This was confirmed by a model developed to test if VT could predict abstinence from sex, and thus protect girls from STIs. Virginity testing was not found to be a protective factor (OR $0.84,95 \% \mathrm{Cl} 0.50,1.41$ ) in preventing sexual intercourse. Neither was any association found between girls participating in virginity testing and their use of condoms (Chi-square 0.38, $\mathrm{P}=0.81)$

The study also investigated whether girls who participated in virginity testing would be less likely to engage in other risky behavior such as substance use which is 
Table 3: Differences in responses between girls who would participate or not participate in Virginity Testing (VT)

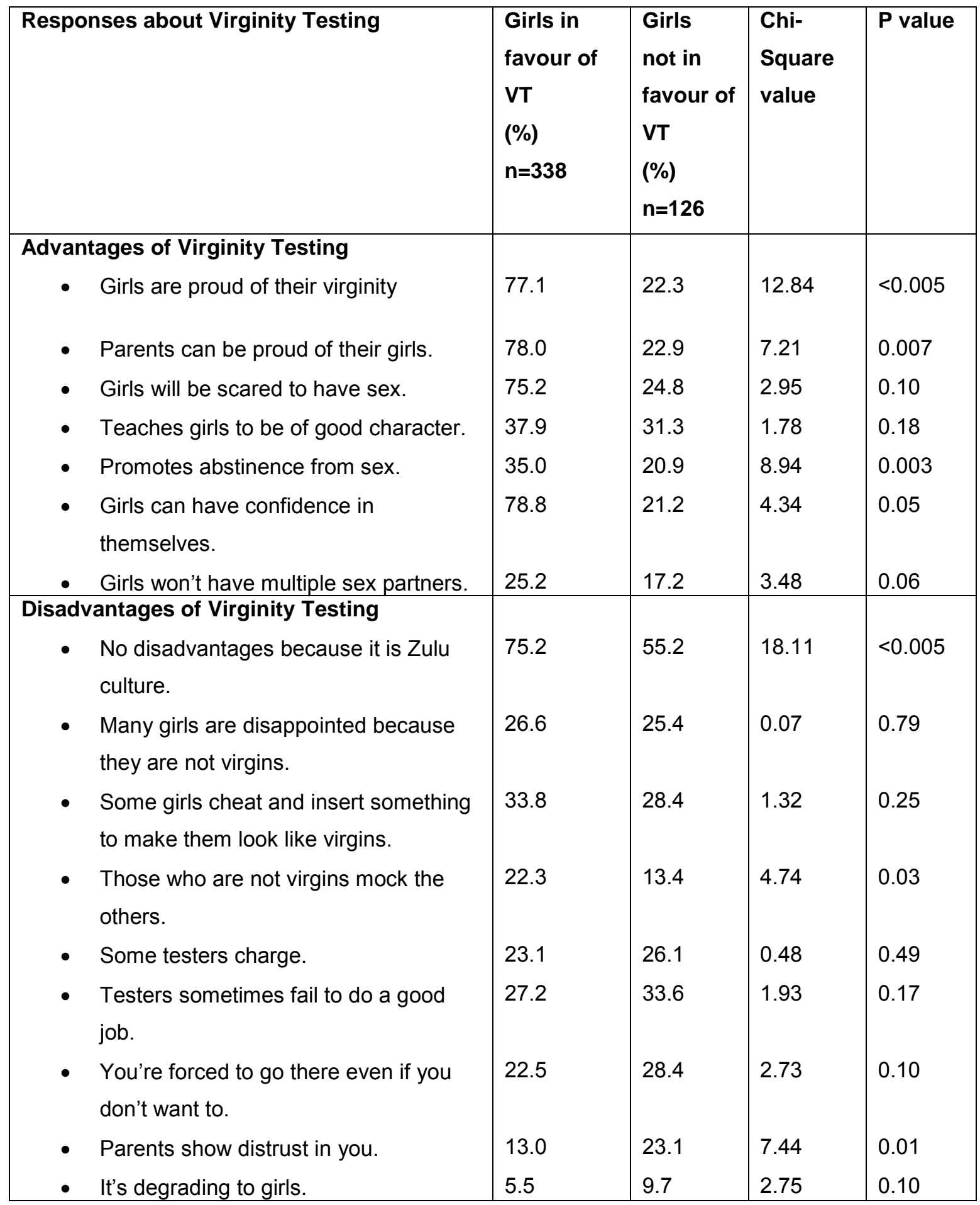


a possible risk factor for unsafe sex and could increase the possibility of HIV infection. A second model was developed to test this. Significantly fewer girls who participated in VT smoked cigarettes (OR 0.27, 95\% Cl $0.09,0.78)$, but the total number of girls smoking was low $n=17$ (3.8\%). The cultural practice of VT was not found to protect girls from other risky behavior such as alcohol consumption or the use of cannabis.

\section{DISCUSSION}

This study has found that amongst rural isiZulu-speaking secondary school students the prevalence of VT is high and there is substantial support for such testing amongst girls of different ages, with VT acknowledged and respected as a traditional practice. However, it is a practice that fell into disuse for many decades and its use is controversial in a country where gender equity and human rights are entrenched in the Constitution (Reuters, 2001:1, Constitution of the Republic of South Africa, 1996:7-37). The study investigated the perceptions of both sexes since males are often dominant in decision-making in Zulu culture, and a better understanding of both sexes' attitudes to VT is required. Students at these rural schools perceived more advantages than disadvantages concerning the practice.

Due to social pressure, sexually active girls also participated in VT and were able to do this successfully as they indicated that they would also participate in the future. VT therefore did not deter these girls from sexual activity, nor did engaging in VT promote safe sex practices such as condom use and it also did not protect these girls from sexually transmitted infections. Lack of contraception and condom use by teenagers is evident in the high rate of teenage pregnancy, indicating that many young people are at risk of HIVIAIDS (DOH, 1998:142; Reddy et al. 2003:51-56). This lack of condom use was confirmed by another KZN study where $51.7 \%$ of sexually active girls reported having been pregnant, with more pregnancies amongst girls in rural areas (Manzini, 2001:1744-52). In this study VT was not associated with decreased use of alcohol or cannabis, other risk behaviours prevalent in KwaZuluNatal and associated with unsafe sex (Taylor, Jinabhai, Naidoo, Kleinschmidt \& Dlamini, 2003:136-141).

The significant gender differences in respect of support for VT were in relation to abstinence from sex and the rationale that virginity should be a source of pride for girls and their parents. The perception that it would empower girls and improve their self-confidence also drew less male support. VT was considered by supporters of both sexes not only to be a protective strategy particularly against pregnancy, but also against sexually transmitted infections and HIVIAIDS. All the girls, including those not in favour of VT, acknowledged its important role in Zulu culture. However, girls in favour of participating in VT perceived more personal advantages and fewer disadvantages, and were significantly less likely to consider it a sign of parental distrust than girls not in favour.

HIVIAIDS is taking a high toll amongst young people in KwaZulu-Natal and is now at the stage of a mature epidemic, with many people infected with HIV and increased mortality, particularly amongst women in their twenties from AIDS (Dorrington, Bourne, Bradshaw, Laubscher \& Timaeus, 2001:1-58). VT is a response of Zulu communities to this scenario, to reduce the rate of infection. VT is however also regarded as "unconstitutional, unhygienic and violates the human rights of those being tested" (Reuters, 2001:1). The focus on women as opposed to acknowledging the co-responsibility of men, discriminates against women and reinforces the stereotypical perspective of female responsibility. Furthermore, South Africa's Constitution stands firmly on the side of Human Rights and the Bill of Rights is entrenched in the 1996 Constitution. Girls who are compelled to participate in VT have their rights and dignity violated. It is a discriminatory practice since males are not tested and it is against the Convention of the Rights of the Child to which South Africa is a signatory. A tension thus exists amongst communities between the support for traditional practices and the new external and legally binding influences of "rights" embodied in the Constitution. The dilemma therefore, is between VT as a traditional cultural practice that enforces internal socialisation but that is in conflict with human rights. Culture however is not stagnant, and the practice of VT fell into disuse with increasing urbanisation and westernisation, but was re-introduced in the latter half of the1990s as a response to the HIVIAIDS epidemic.

VT is also not without danger in a milieu where forced sex was reported by over a quarter of sexually active female students (Taylor et al. 2002:69-74). Although few people claim to support the belief that sex with a 
virgin can cure AIDS (Shishana et al. 2005:82), child rape in South Africa is a major concern and in such an environment identifying girls as virgins may be placing them at risk. Tillotson and Maharaj (2001:83-100) in their study of Zulu-speaking township males report that virgins were seen as "safe", and not requiring the use of condoms by males of 15-23 years of age. Involving girls in VT however does little to respond to the issues of gender equity and sexual violence against women, nor does it address perceptions that traditional culture favours multiple partners (Varga, 1997:13-41).

The study relied on students' self-reports and although confidentiality was stressed, and the survey was anonymous, it was undertaken on the school premises which may have influenced students' responses, either to exaggerate or limit the information provided.

\section{CONCLUSION}

Although South Africa's Bill of Rights provides for gender equity, the policy has yet to be fully implemented. This study indicates that VT has substantial grassroots support, but VT did not prevent sexual activity and sexually active female students indicated that they could undergo VT. Hence, VT as an HIV prevention strategy in South Africa is unlikely to be effective. It is the underlying problems in respect of gender equity, sexual decision-making regarding safe-sex and multiple partners that need to be addressed to reduce HIV incidence, and the school has an important role to play in the provision of life skills' education.

\section{Acknowledgements}

SANPAD (South Africa - Netherlands Partnership for Alternative Development) for funding.

\section{REFERENCES}

BUGA, GA; AMOKO, DH \& NCAYIYANA, DJ 1996: Sexual behaviour, contraceptive practice and reproductive health among school adolescents in rural Transkei. South African Medical Journal, 86(5):523-527.

CONSTITUTION OF THE REPUBLIC OF SOUTHAFRICA 1996: Act 108 of 1996. Chapter 2, Bill of Rights, 7-37. Available from: http:// www.info.gov.za/documents/constitution/1996/96cons2.htm\#9. (Accessed: 24 May 2007).

DEPARTMENT OF HEALTH 1998: South Africa Demographic and
Health Survey 1998. Full Report. Pretoria: Department of Health. DEPARTMENT OF HEALTH 2002: National HIV and Syphilis SeroPrevalence survey of women attending public antenatal clinics in South Africa 2002. Pretoria: Department of Health.

DEPARTMENT OF HEALTH 2005: National HIV and Syphilis SeroPrevalence survey of women attending public antenatal clinics in South Africa 2004. Pretoria: Department of Health.

DE VRIES, H; BACKBIER, E; KOK, G \& DIJKSTRA, M 1995: The impact of social influences in the context of attitudes, self-efficacy, intention and previous behavior as predictors of smoking onset. Journal of Applied Social Psychology, 25(3):237-257.

DE VRIES, H; MUDDE, A; LEIJS, I; CHARLTON, A; VATTIAINEN, E; BUIJS, G; PAIS CLEMENTE, M; STORM, H; GONZALEZNAVARRO, A; NEBOT, N; PRINS, T \& KREMERS, S 2003: The European Smoking Prevention Framework Approach (EFSA): An example of integral prevention. Health Education Research, 18(5):611-626. DORRINGTON, R; BOURNE, D; BRADSHAW, D; LAUBSCHER, R \& TIMAEUS, I 2001: The impact of HIVIAIDS on adult mortality in South Africa. Technical Report. Cape Town: Medical Research Council.

HARRISON, A; XABA, N; KUNENE, A \& NTULI, N 2001: Understanding young women's risk for HIVIAIDS: Adolescent sexuality and vulnerability in rural KwaZulu-Natal. Society in Transition, 32(1):69-78.

LECLERC MADLALA, S 2001: Virginity testing: Managing sexuality in a maturing HIVIAIDS epidemic. Medical Anthropology Quarterly, 15(4):533-553.

MANZINI, N 2001: Sexual initiation and childbearing among adolescent girls in KwaZulu-Natal, South Africa. Reproductive Health Matters, 9(17):1744-52.

MURPHY, DE 1999: A time of testing in virginity. The Los Angeles Times, 15 July 1999. Available from: http://www.aegis.com/ news/lt/1999/LT990702.html (Accessed: 21 May 2007).

REDDY, SP; PANDAY, S; SWART, D; JINABHAI, CC; AMOSUN, SL; JAMES, S; MONYEKI, KD; STEVENS, G; MOROJELE, N; KAMBARAN, NS; OMARDIEN, RG \& VAN DEN BORNE, HW 2003: Umthente, Uhlaba, Usamila. The South African youth risk behaviour survey 2002. Cape Town: Medical Research Council.

REUTERS, Johannesburg 2001: Virginity tests on comeback trail in South Africa. Jenda: Journal of Culture and African Women Studies, 1(1). Available from: http://www.jendajournal.com/ vol1.1/virginity.html. (Accessed: 24 May 2007).

SATHIPARSAD, R \& TAYLOR, M 2006: "Diseases come from girls": Perspectives of male learners in rural KwaZulu-Natal on HIV infection and AIDS. Journal of Education, 38:117-137.

SHISANA, O \& SIMBAYI, L 2002: Nelson Mandela/HSRC Study of HIVIAIDS. South African National HIV Prevalence, Behavioural Risks and Mass Media Household Survey 2002. Cape Town: Human Sciences Research Council. 
SHISANA, O; REHLE, T; SIMBAYI, LC; PARKER, W; ZUMA, K; BHANA, A; CONNOLLY, C; JOOSTE, S \& PILLAY V 2005: South African National HIV prevalence, behavioural risks and mass media. Nelson Mandela/Human Science Research Council Study of HIVI AIDS. Pretoria: Human Sciences Research Council.

STATISTICS SOUTH AFRICA 2000: Stats in Brief 2000. Pretoria: Statistics South Africa.

TAYLOR, M; JINABHAI, CC; DLADLA, NA; RANGONGO, MF \& CONNOLLY, C 2000: HIVIAIDS health education for rural KwaZuluNatal primary school students. South African Journal of Epidemiology and Infection, 15(4):100-107.

TAYLOR, M; DLAMINI, SB; KAGORO, H; JINABHAI, CC; SATHIPARSAD, R \& DE VRIES, H 2002: Self-reported risk behaviour of learners at rural Kwazulu-Natal high schools. Agenda, 53:6974.

TAYLOR, M; JINABHAI, CC; NAIDOO, K; KLEINSCHMIDT, I \& DLAMINI, SB 2003: An epidemiological perspective of substance use among high school students in rural KwaZulu-Natal. South African Medical Journal, 93(2):136-141.

TILLOTSON, J \& MAHARAJ, P 2001: Barriers to HIVIAIDS protective behaviour among African adolescent males in township Secondary Schools in Durban, South Africa. Society in Transition, 32(1):83-100.

VARGA, C 1997: Sexual decision-making and negotiation in the midst of AIDS. Youth in KwaZulu-Natal, South Africa. Health Transition Review, 7(Supplement 3):45-67. 